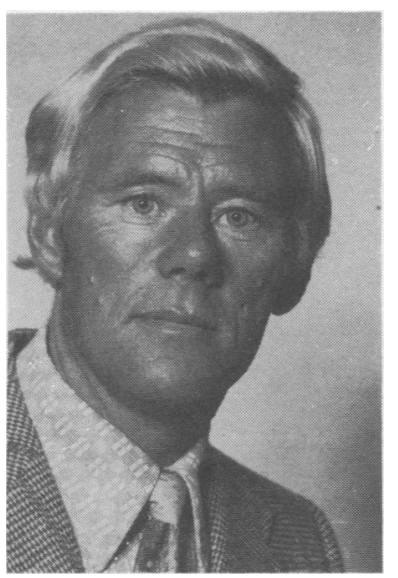

\title{
THE RELATIONSHIP OF PHYSIQUE AND BODY COMPOSITION TO STRENGTH IN A GROUP OF PHYSICAL EDUCATION STUDENTS
}

\author{
P. BALE, MIBiol, DipEd, MBPS, PhD \\ Senior Lecturer, Chelsea School of Human Movement, Brighton Polytechnic
}

\begin{abstract}
Key words: Anthropometry, Somatotype, body composition, strength.
In a recent study by the author (Bale, 1979) a significant relationship was obtained between the physique of women physical education students and their performance in motor activities involving strength, speed, agility and balance. One test item which correlated most highly with mesomorphy (muscularity in relation to height) was grip strength $(r=75)$. However, this raises the questions, would as high a relationship be obtained between somatotype and other measures of strength and what would be the relationship between body composition and strength?
\end{abstract}

ABSTRACT

Fifty-three specialist women physical education students were measured anthropometrically and from these measurements somatotype and body composition were estimated. Leg, back and grip strength dynamometers were used to measure strength indices. Arm strength was calculated from each subject's pull-ups and push-ups and lung capacity was measured using a spirometer. The somatotype ratings and percent fat measurements indicate that the P.E. students are generally more muscular and less fat for their age than non-P.E. students. There was a strong relationship between percent fat and the endomorphy rating and a moderate relationship between lean body weight and mesomorphy. The moderate relationship of the strength variables with the muscular rating, whether expressed as mesomorphy or lean body weight, suggests that the higher a subject's muscular component the greater their dynamic strength.

The purpose of this study therefore, was to examine the relationship of somatotype and body composition to strength in a group of women physical education students. Fifty-three students were measured anthropometrically on a total of nine sites. Skin folds were measured using Harpenden calipers with a caliper tension of $10.3 \mathrm{~g} \cdot \mathrm{mm}^{-2}$. Bicondylar measurements were made using the "Harpenden" anthropometer and circumferences with a constant tension steel tape. Height in $\mathrm{cm}$ and weight in $\mathrm{kg}$ were also measured. All the skin folds were taken with the subject in a standing position except for the biceps fold for which the subject sat on a chair and rested her arm in supination.

Because of the difficulty in obtaining an accurate skin fold measurement over the calf in girls who partic- ipate in physical activity, the Parnell M4 method (Parnell, 1958) of estimating Somatotype was selected in preference to the Heath-Carter method (1967). Body composition can be assessed precisely using complex, lengthy and expensive laboratory techniques such as volumetric displacement, hydrostatic weighing, total body water, body potassium and radiography (Behnke and Wilmore, 1974), but density, body fat and lean body weight were assessed in this study by calculations based upon body weight and total skin folds. Two regression equations were selected; the first, was to estimate body density from the logarithm of the sum of the biceps, triceps, subscapular and suprailiac skin folds. Logarithmic instead of absolute values are used since the relationship of skin folds to density is curvilinear and not rectilinear and because skin folds have a skewed distribution in the body. (Durnin and Rahaman, 1967, Durnin and Womersley, 1974).

$$
\begin{aligned}
& \text { Density }=1.1599-0.0717 \times \log \Sigma \text { Skin folds } \\
& \% \text { Body Fat }=\frac{(4.95-4.5)}{D} \times 100 \quad \text { (Siri } 19
\end{aligned}
$$

Absolute Body fat $(\mathrm{kg})=$ Body weight $x \%$ Body Fat 100

Lean Body Weight $=$ Body Weight - Absolute Body Fat 
The second method used the triceps, subscapular and thigh skin folds in the following equations (Wilmore and Behnke, 1970).

$\begin{aligned} \text { Density = } & 1.06234-(0.00068) \times \text { Scap- } \\ & \text { ular skin fold }(\mathrm{mm})-(0.00039 \\ & \times \text { triceps skin fold } \mathrm{mm})- \\ & (0.00025 \times \text { thigh skin fold } \\ & \mathrm{mm}) \\ \text { Lean Body Weight }= & 8.629+(0.680 \times \text { Weight } \mathrm{kg})- \\ & (0.163 \times \text { Scapular skin fold } \\ & \mathrm{mm})-(0.1 \times \text { triceps skin } \\ & \text { fold } \mathrm{mm})-(0.054 \times \text { thigh } \\ & \text { skin fold } \mathrm{mm})\end{aligned}$

Both estimates are considered by their authors to have a high reliability and both accurately estimate percentage fat and lean body weight when compared with direct estimation obtained from underwater weighing or body potassium methods. However, in an analysis of various prediction equations Wilmore and Behnke (1970) did state that predictive accuracy was "limited by the degree of similarity between the original and independent samples".

The Rogers Strength Index (1925) was chosen to measure strength because of its high relationship with general athletic ability, as he obtained correlations between $r=.77$ and .81 between the index and the hundred yard dash, high jump, standing broad jump, shot put and various tests of throwing ability. The Strength Index and its sub-tests are also related significantly to those skills necessary for success in physical education (Welman, 1935, Wessel and Nelson, 1961).

The Strength Index includes measurement of the subject's pull-ups and push-ups which are combined in the following formula:

$$
\text { (Pull-ups + Push-ups) } \frac{\text { (Weight }+ \text { Height }-60)}{(10}
$$

to give arm strength. A hand dynamometer was used to test grip strength in both hands and a dynamometer was used to measure back strength and leg lift. Lung capacity was measured by a Benedict-Roth spirometer. Though the relationship of lung capacity with strength is no longer regarded with the same confidence, the item is still included as part of the test battery. The index is calculated by adding the six scores of arm strength, right and left grip, back strength, leg lift and lung capacity.

\section{RESULTS AND DISCUSSION}

The mean values of the physique measurements are shown in Table I.

\section{TABLE I}

$\begin{array}{lcrc}\begin{array}{l}\text { Physique } \\ \text { Mossurement }\end{array} & \text { Range } & \text { Mean } & \begin{array}{r}\text { Standard } \\ \text { Deviation }\end{array} \\ \text { Height in cm } & 153.2-180 & 166.23 & 5.4 \\ \text { Weight in kg } & 48.8-80.2 & 61.29 & 7.4 \\ \text { Ponderal Index } & 11.3-13.7 & 12.85 & 0.5 \\ \text { Endomorphy } & 2-5.0 & 3.41 & 0.74 \\ \text { Mesomorphy } & 2-5.5 & 3.72 & 0.74 \\ \text { Ectomorphy } & 1-5.0 & 2.99 & 1.10\end{array}$

The physiques of the physical education students in this study compare closely with those values obtained in earlier studies (Bale, 1969, 1978, 1979) and with similar studies of other women physical education students from New Zealand and America (Carter, 1965, Cockeram, 1975, Perbix, 1954). As the somatochart (Fig. 1) shows, most students have balanced, mesomorphic endomorph or endomorphic mesomorph physiques indicating that women P.E. students are less fat and more muscular than non-P.E. students. In contrast to the girls' somatotypes in this study most female somatotypes lie towards the endomorphy area of the somatochart (Sheldon, et al 1954, Parnell, 1958).

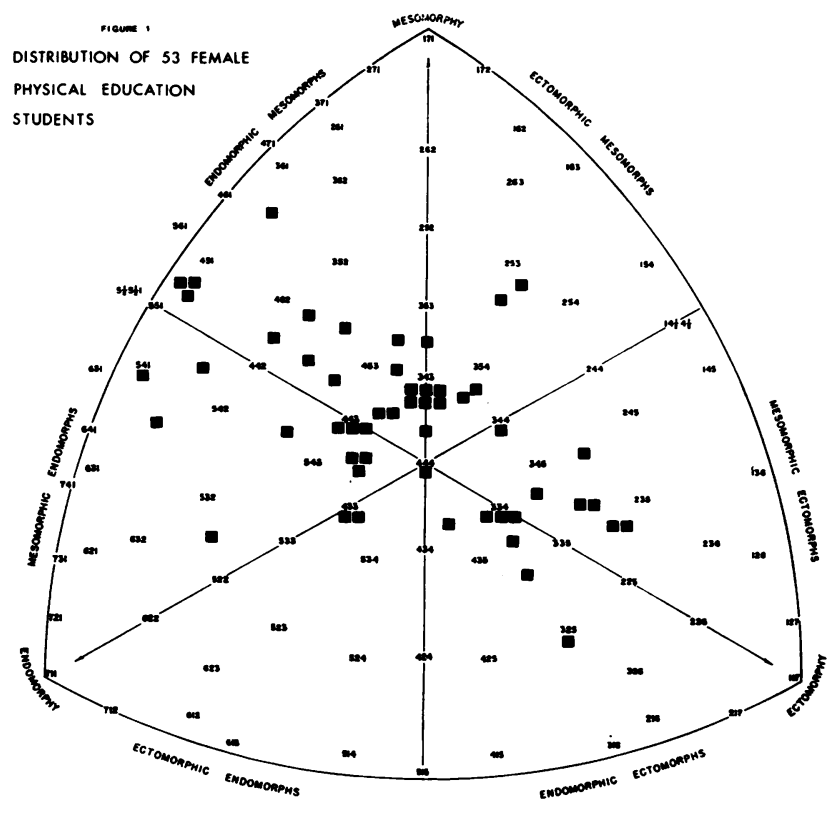

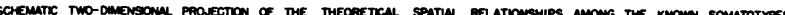

The mean scores for the two estimates of density, absolute body fat, percent fat, and lean body weight and the correlations between them are shown in Table II. 


\section{TABLE ॥}

\begin{tabular}{|c|c|c|c|}
\hline & $\begin{array}{l}\text { Durnin \& } \\
\text { Rahaman }\end{array}$ & $\begin{array}{l}\text { Wilmore \& } \\
\text { Behnke }\end{array}$ & Correlation \\
\hline Density $\left(\mathrm{g} . \mathrm{cm}^{3}\right)$ & $\begin{array}{l}1.045 \\
\sigma=0.008\end{array}$ & $\begin{array}{l}1.044 \\
\sigma=0.005\end{array}$ & 0.91 \\
\hline $\begin{array}{l}\text { Absolute Body } \\
\text { Fat (kg) }\end{array}$ & $\begin{array}{l}14.61 \\
\sigma=3.96\end{array}$ & $\begin{array}{l}14.92 \\
\sigma=3.49\end{array}$ & 0.95 \\
\hline$\%$ Fat & $\begin{array}{l}23.56 \\
\sigma=3.82\end{array}$ & $\begin{array}{l}24.42 \\
\sigma=2.58\end{array}$ & 0.90 \\
\hline $\begin{array}{l}\text { Lean Body } \\
\text { Weight (kg) }\end{array}$ & $\begin{array}{l}46.68 \\
\sigma=4.32\end{array}$ & $\begin{array}{l}46.18 \\
\sigma=4.02\end{array}$ & 0.96 \\
\hline
\end{tabular}

As expected body composition calculated from the two regression equations was similar, though the the 1970 equation of Wilmore and Behnke resulted in slightly higher fat and lower lean body weight estimates than did the 1967 equation of Durnin and Rahaman.

Comparison of the above measures with those obtained by other researchers using estimation of body composition from anthropometric measurement and by direct measurement also support the view that the physical education students are generally less fat for their age than non-P.E. women. Durnin and Womersley (1974) for example, obtained a density of 1.040 and $26 \%$ Fat in their 16-19 year old and 1.034 and $29 \%$ Fat in their 20-29 year old groups of women using the same estimate of body composition as was used in this investigation. Wilmore's and Behnke's (1970) underwater weighing method of measuring body composition in a group of women students the same age as my students resulted in a mean body density of $1.041, \%$ Fat 25.73 and lean body weight of $43.37 \mathrm{~kg}$. Similar findings were obtained by the underwater weighing method from groups of college students by Katch and McArdle (1973) and by Slaughter and Lohman (1976). When compared with other female athletes the P.E. students in this study had similar values percent fat as tennis players and track and field athletes (Katch, Micheal and Jones, 1969, Brown and Wilmore, 1971) but higher values than women gymnasts, distance runners, skiers and basketball players (Sinning and Lindberg, 1972; Wilmore and Brown, 1974; Vaccaro, Clarke and Wrenn, 1979). Young and Blondin (1962), Young, Martin et al. (1962) and Mayhew and Gross (1974) obtained much lower densities and much higher measurements for percentage fat and lean body weight in their studies of non-P.E. students than were achieved in this study. However, the similar estimates of body composition to those obtained in the present study (MacMillan, Reid et al., 1965, Sloan, Burt and Blyth, 1962, Slaughter, Lohman and Boileau, 1977) and the lower estimate obtained by Katch and Micheal (1968) in non-P.E. and non-athletic students suggest that factors other than physical activity account for the differences observed in body compos- ition measurements between groups. The latter investigators for example, suggest that climatic and seasonal variations, diet and genetic factors may also partially account for these differences.

The means and standard deviations of the scores of the strength measures were calculated and are presented in Table III.

\section{TABLE III}

$\begin{array}{lccr}\text { Strength Measure } & \text { Range } & \text { Mean } & \text { S.D. } \\ & & & \\ \text { Arm Strength (Ibs.) } & 125-1337 & 427.08 & 261.28 \\ \text { Left Grip (Ibs.) } & 60-104 & 85.54 & 10.02 \\ \text { Right Grip (Ibs.) } & 64-110 & 91.65 & 9.36 \\ \text { Leg Lift (Ibs.) } & 118-449 & 229.67 & 73.49 \\ \text { Back Strength (Ibs.) } & 101-284 & 211.71 & 42.63 \\ \text { Lung Capacity } & & & \\ \text { (litres) } & 2.41-5.10 & 3.62 & 0.54 \\ \text { Strength Index } & 859-2273 & 1260 & 317\end{array}$

The mean scores for grip strength by the students in this study are similar to those obtained by Heyward and McCreary (1977) in their study of women athletes and to those achieved by élite basketball players tested by Vaccaro, Clarke and Wrenn (1979) and they are superior to the grip strength scores achieved by non-P.E. students tested by Mayhew and Gross (1974) even after these students had completed a nine-week period of circuit weight training. When the scores for left and right grip were combined the mean combined score achieved by the P.E. students of $80.06 \mathrm{~kg}$. was over $30 \mathrm{~kg}$. higher than the mean score achieved by nearly six hundred women of the same age tested by Montoye and Lamphiear (1977). However, the arm strengths, leg lifts and strength indices of the P.E. students in this study were inferior to those achieved by Vaccaro's élite basketball players who were taller, heavier, had greater lean body weights and lower percent fats than the P.E. students.

Montoye and Lamphiear also tested arm strength in a large sample of girls and older women using a dynamometer and overhead pulley system. In every age group they tested the ratio of arm strength to body weight was less than one. They comment that, "pull-ups is not a good test for girls, since more than half of them cannot exert a force equal to their body weight". This applies to push-ups also. As the large standard deviation and wide range of scores for arm strength achieved by the students in this study show, many of them had difficulty in doing this test which greatly influenced their overall strength index score.

In order to examine the relationship between physique, body composition and strength variables a multiple correlation analysis was computed (Table IV). 
TABLE IV

\begin{tabular}{|c|c|c|c|c|c|c|c|c|c|c|c|c|c|c|c|c|}
\hline Variable & 1 & 2 & 3 & 4 & 5 & 6 & 7 & 8 & 9 & 10 & 11 & 12 & 13 & 14 & 15 & 16 \\
\hline 1. Height & & 34 & 40 & -01 & -37 & 41 & -08 & 07 & 18 & 41 & -15 & 24 & 28 & 23 & -02 & 43 \\
\hline 2. Weight & & & -70 & 73 & 40 & -65 & -71 & 71 & 88 & 90 & 08 & 47 & 37 & 32 & 18 & 30 \\
\hline 3. Ponderal Index & & & & -69 & -67 & 96 & 63 & -63 & -70 & -55 & -21 & -28 & -16 & -17 & -18 & 04 \\
\hline 4. Endomorphy & & & & & 20 & .72 & -95 & 95 & 92 & 41 & -12 & 17 & 16 & 14 & 15 & 13 \\
\hline 5. Mesomorphy & & & & & & -64 & -19 & -19 & 28 & 43 & 41 & 44 & 4019 & 19 & 20 & .02 \\
\hline 6. Ectomorphy & & & & & & & 62 & -62 & -67 & -50 & -22 & -34 & -23 & -14 & -20 & 01 \\
\hline 7. Body Density & & & & & & & & -99 & -95 & -35 & 13 & -11 & -11 & -09 & -08 & -09 \\
\hline 8. \% Fat & & & & & & & & & 95 & 35 & -13 & 11 & 11 & 09 & 08 & 09 \\
\hline 9. Absolute Fat & & & & & & & & & & 67 & -07 & 26 & 20 & 18 & 15 & 17 \\
\hline 10. L.B.W. & & & & & & & & & & & 18 & 58 & 45 & 38 & 18 & 35 \\
\hline 11. Arm Strength & & & & & & & & & & & & 25 & 30 & 16 & 11 & 02 \\
\hline 12. Left Grip & & & & & & & & & & & & & 81 & 26 & 25 & 35 \\
\hline 13. Right Grip & & & & & & & & & & & & & & 31 & 36 & 47 \\
\hline 14. Leg Lift & & & & & & & & & & & & & & & 69 & 27 \\
\hline 15. Back Strength & & & & & & & & & & & & & & & & 31 \\
\hline 16. Lung Capacity & & & & & & & & & & & & & & & & \\
\hline
\end{tabular}

$$
\begin{aligned}
& r=.23 P>0.05 \\
& r=.32 P>0.01 \\
& r=.40 P>0.001
\end{aligned}
$$

All decimal Points are omitted

Somatotype describes body morphology and structure as well as body composition and therefore, by definition, some degree of relationship between somatotype and body composition is to be expected. The zero order correlations between the physique components and body composition estimates do indicate a high relationship between percent fat and endomorphy (.94) which is to be expected as both were estimated from skin fold measurements. Similar studies on women students (Slaughter and Lohman, 1976, Slaughter, Lohman and Boileau, 1977) and on children (Hunt and Barton, 1959, Slaughter and Lohman, 1977) also indicate a close relationship between endomorphy and body fat. There was a moderate negative relationship between lean body weight and ectomorphy and a moderate positive relationship between lean body weight and mesomorphy. Wilmore (1970) in his study of male and female college students and Slaughter and Lohman (1976), Slaughter, Lohman and Boileau (1977) in their studies of women students found only low relationships between these two components. They comment that, since mesomorphy (which they assessed by the HeathCarter Anthropometric method) is defined as lean body weight in relation to height rather than the absolute weight of lean body mass, it is not surprising that mesomorphy and lean body mass are not closely related.

Both lean body weight and mesomorphy were moderately related to the indices of strength. Though it was not as high as that achieved in an earlier study (Bale, 1979), a significant relationship was obtained between grip strength and mesomorphy. Moderate correlations were also obtained between mesomorphy and arm strength, mesomorphy and the overall strength index and between lean body weight and grip strength. Lower but still significant relationships were obtained between lean body weight, leg lift and lung capacity. These findings suggest that the higher a person's muscular rating, whether expressed as mesomorphy or lean body weight, the greater their dynamic strength. Care must be taken, however, not to over-emphasise the relationship between body composition, physique and strength on the basis of the above findings. Back strength, for example, showed little relationship with either mesomorphy or lean body weight. Apart from a relationship between weight and grip strength the other physique variables and measures of body composition were not related to strength. 


\section{REFERENCES}

Bale, P., 1969 "Somatotyping and body physique". Physical Education 61: 75-82.

Bale, P., 1978 "The physiques of physical edcuation students and their relationships to performance". Research Papers in Physical Education 3: 4, 30-33.

Bale, P., 1979 "The relationship between physique and basic motor performance in a group of female physical education students". Research Papers in Physical Education 1: 26-32.

Barry, A. and Cureton, T. K., 1961 "Factorial analysis of physique and performance in prepubescent boys". Research Quarterly 32: 283-300.

Behnke, A. R., and Wilmore, J. H., 1974 Evaluation and regulation of body build and composition. Prentice Hall.

Brown, C. H., and Wilmore, J. H., 1971 "Physical and physiological profiles of champion women long distance runners". Medicine and Science in Sports, 3: 1.

Burkinshaw, L., Jones, P. R. and Krupowicz, D. W., 1973 "Observer error in skin fold thickness measurements". Human Biology, 45: 273-279.

Carter, J. E. L., 1965 "The physiques of female physical education teachers in training". Physical Education 57: 6-16.

Cockeram, B. W., 1975 "Physiques of arts and physical education students". New Zealand Journal of Health P.E. and Recreation, 8: 62-66.

Durnin, J. V. and Rahaman, M. M., 1967 "The assessment of the amount of fat in the human body from measurements of skin fold thickness". British Journal of Nutrition 21: 681-689.

Durnin, J. V. and Womersley, J., 1974 "Body fat assessed from total body density and its estimation from skin fold thickness measurements on 481 men and women aged from 16-72 years". British Journal of Nutrition, 32: 77-97.

Heyward, V. and McCreary, L., 1977 "Analysis of the static strength and relative endurance of women athletes". Research Quarterly, 48: 703-710.

Heath, B. H. and Carter J. E. L., 1967 "A modified somatotype method". American Journal of Physical Anthropology, 27: 57-74.

Hirata, K., 1966 "Physique and age of Tokyo Olympic champions". Journal of Sports Med.and Physical Fitness, 6: 20F, 222.

Hunt, E. and Barton, W. H., 1959 "The inconstancy of physique in adolescent boys and other limitations of somatotyping". American Journal of Physical Anthropology, 17: 27-35.

Katch, F. and Micheal, E., 1968 "Prediction of body density from skin fold and girth measurements of College females". Journal of Applied Physiology, 25: 92-94.

Katch, F., Micheal, E. D. and Jones, E. M., 1969 "Effects of physical training on the body composition and diet of females". Research Quarterly, 40: 49-104.

Katch, F. and McArdle, W., 1973 "Prediction of body density from simple anthropometric measurements". Human Biology, 45: 445-454.

Lampiear, D. E. and Montoye, H. J., 1976 "Muscular strength and body size”. Human Biology, 48: 147-160.

MacMillan, M. G., Reid, C., Shirling, D. and Passmore, R., 1965 "Body composition, resting oxygen consumption, and urinary excretion in Edinburgh students". Lancet, 1: 728-729. 
Mayhew, J. L. and Gross, P. M., 1974 "Body composition changes in young women with high resistance weight training". Research Quarterly, 45: 433-440.

Montoye, H. J. and Lamphiear, D. E., 1977 “Grip and arm strength in males and females, age 10 to 69 ". Research Quarterly, 48: 109-120.

Parnell, R. W., 1958 "Behaviour and physique". Arnold Co., London.

Perbix, J., 1954 "Relationship between somatotype and motor fitness in women". Research Quarterly, 25: 84-90.

Rogers, F. R., 1925 "Physical capacity tests in the administration of physical education". New York Bureau of Publications, Teacher College, Colombia University.

Sheldon, W. H., Dupertuis, C. W. and McDermott, E., 1954 "Atlas of men". Harper Bros, New York.

Siri, W. E., 1956 "The gross composition of the body" in Advances in Biological and Medical Physics edited by J. E. Lawrence and C. A. Tobias, Academic Press.

Sinning, W. E. and Lindberg G. D., "Physical characteristics of college age women gymnasts". Research Quarterly, 43: 226-234.

Sheldon, W. H., Stevens, S. S. and Tucker, W. B., 1954 "Varieties of human physique". Harper Bros., New York.

Slaughter, M. H. and Lohman, T. G., 1976 "Relationship of body composition to somatotype". American Journal of Physical Anthropology 44: 237-244.

Slaughter, M. H. and Lohman, T. G., 1977 "Relationship of body composition to somatotype in boys ages 7 to 12 years". Research Quarterly, 48: 750-758.

Slaughter, M. H., Lohman, T. G., and Misner, J. E., 1977 "Relationship of somatotype and body composition to physical performance in 7 to 12 year olds boys". Research Quarterly, 48: 160-168.

Slaughter, M. H., Lohman, T. G. and Boileau, R. A., 1977 “Relationship of Heath and Carter's second component to lean body mass and height in college women". Research Quarterly, 48: 759-768.

Sloan, A. W., Burt, J. J. and Blyth, C. S., 1962 "Estimation of body fat in young women". Journal of Applied Physiol. ogy. 17: 967-970.

Vaccaro, P., Clarke, D. H. and Wrenn, J. P., 1979 "Physiological profiles of élite women basketball players". Journal of Sports Medicine and Phys. Fitness, 19: 45-54.

Welman, E. B., 1935 "The validity of various tests as measures of motor ability". Supplement to Research Quarterly.

Wessel, J. A. and Nelson, R. C., 1961 "Relationship between grip strength and achievement in physical education among college women". Research Quarterly, 32: 244-248.

Wilmore, J. H., 1970 "Validation of the first and second components of the Heath Carter modified somatotype method". American Journal of Physical Anthropology, 32: 369-372.

Wilmore, J. H. and Brown, C. H., 1974 "Physiological profiles of women distance runners". Medicine and Science in Sport, 6: 178-181.

Wilmore, J. H. and Behnke, A. R., 1970 "An anthropometric estimation of body density and lean body weight in young women". American Journal of Clinical Nutrition, 23: 267-274.

Young, C. M., Martin, E. K., Tensuan, R. and Blondin, J., 1962 "Predicting specific gravity and body fatness in young women". Journal of American Diet Assoc. 40: 102-107.

Young, C. M. and Blondin, J., 1962 "Estimating body weight and fatness of young women". Journal of American Diet Assoc. 41: 452-455. 